Article

\title{
Incorporation of Immigrants and Second Generations into the French Labour Market: Changes between Generations and the Role of Human Capital and Origins
}

\author{
Yaël Brinbaum ${ }^{1,2}$ \\ ${ }^{1}$ Laboratoire Interdisciplinaire pour la Sociologie Economique (LISE UMR CNRS), Conservatoire National des Arts et Métiers \\ (CNAM), 75003 Paris, France; E-Mail: yael.brinbaum@lecnam.net \\ ${ }^{2}$ Centre d'Études de l’Emploi et du Travail (CEET), Conservatoire National des Arts et Métiers (CNAM), 75003 Paris, France
}

Submitted: 28 February 2018 | Accepted: 21 June 2018 | Published: 30 July 2018

\begin{abstract}
This article analyses the labour market incorporation of migrants and second-generation minorities in France. Using the 2013-2017 French Labour Surveys and the 2014 adhoc module, we focus on labour market outcomes-activity, employment, occupation and subjective overqualification-and measure the gaps between ethnic minorities and the majority group by origins, generation and by gender. In order to elucidate the mechanisms behind these gaps and explain ethnic disadvantages for immigrants, we take into account different factors, such as education, and factors linked to migrationduration of stay in France, language skills, foreign qualifications, nationality-with additional controls for family, socioeconomic and contextual characteristics. We also investigate the returns to higher education among second-generation minority members compared to the majority population. We show large differences by country of origins, generation and gender. Across generations, most minority members have made clear progress in terms of access to employment and skilled jobs, but ethnic penalties remain for the descendants of North-Africa, Sub-Saharan Africa and Turkey. In contrast, Asian second-generation men and women encounter slight advantages in attaining highly-skilled positions. Controlling for tertiary degrees even increases the gap with majority members mostly in access to highly-skills jobs.
\end{abstract}

\section{Keywords}

discrimination; employment; France; human capital; immigrants; labour market; returns to higher education; second generation; skilled workers

\section{Issue}

This article is part of the issue "The Race for Highly-Skilled Workers", edited by Neli Demireva (University of Essex, UK) and Ivana Fellini (University of Milano Bicocca, Italy).

(C) 2018 by the author; licensee Cogitatio (Lisbon, Portugal). This article is licensed under a Creative Commons Attribution 4.0 International License (CC BY).

\section{Introduction}

In a context of increasing immigration into Europe, the issue of the integration of migrants and their children lies at the heart of current social, economic and academic debates. Their labour market incorporation is an important issue with consequences for economic integration, social mobility and cohesion.

Immigration in France is an old phenomenon with records of migrant waves since the 19th century (Noiriel, 1988). Immigrants and their descendants constitute a diverse population, and successive waves of immigration have contributed to this diversity (Beauchemin, Hamel, \& Simon, 2016; Brutel, 2014). Second generations from more recent waves of migrations (e.g., from Turkey or South-East Asia) are now in the labour market and may be compared with earlier waves such as those from EU15 countries or North-Africa.

This article analyses the labour market outcomes of immigrants and second-generation minorities in France by comparing these groups to the majority population. We aim at measuring the gaps between generation, country of origin and by gender in order to analyse whether there is an improvement or persistence of eth- 
nic inequalities across generations over time. We also focus on the transferability of educational qualifications. Human capital is an important factor for the obtainment of skilled and stable jobs. It is often assumed that the second generation, socialized and educated in France, should be able to catch up with the majority population in terms of its situation in the labour market. However, scholarly debate in the United States between the assimilation perspective (e.g., Alba \& Nee, 2003) and the segmented assimilation perspective (e.g., Portes \& Rumbaut, 2001; Portes \& Zhou, 1993) is relevant for the French case. ${ }^{1}$ A number of previous studies in France have shown disadvantages in access to employment, particularly pronounced for those with North-African and Sub-Saharan Africa origins (e.g., Brinbaum \& Guégnard, 2013; Brinbaum \& Werquin, 1997, 2004; Frickey \& Primon, 2006; Meurs, Pailhé, \& Simon, 2005, 2006; Silberman, Alba, \& Fournier, 2007; Silberman \& Fournier, 1999; etc.). These disadvantages appear to be reduced and disappear for the second generations when wages are considered (Aeberhardt, Fougère, Pouget, \& Rathelot, 2010; Boumahdi \& Giret, 2005; Dupray \& Moullet, 2004), but exist, in a lesser extent, as to early career job quality (Brinbaum \& Issehnane, 2015).

However, only some research compares the labour market situation of first and second generations due to the lack of the data and the size of the samples by origins in the surveys (in general population), but also because of the difficulties of comparison. Therefore, most research have been focused on the second generation: born and educated in France, they are more comparable and should be able to catch up with the majority population.

The Trajectories and Origins Survey, conducted in 2008, allows us to analyse labour market outcomes for immigrants and their descendants (Beauchemin et al., 2016). In comparison to the majority population, we observe ethnic penalties in employment for non-European immigrants and their descendants, both among men and women (Brinbaum, Meurs, \& Primon, 2016). Differences are also observed among second generations by gender (Brinbaum \& Primon, 2013b). It is important to investigate whether the same patterns can be observed now, as the economic crisis may have accentuated the gaps.

Among immigrants, a number of other factors may shape labour market insertion, such as language skills, the recognition of foreign qualifications, and the role of nationality. Without knowledge of the language, it may be difficult to assert one's skills in the labour market (Chiswick \& Miller, 2014). Recognition of foreign qualifications and transferability of skills into skilled jobs may indeed be a strong barrier for the economic integration of immigrants in Europe (Damas de Matos \& Liebig, 2014). These dimensions are rarely considered because of lack of data, and some variables linked to the experience of migration remain unobservable in the surveys.

We further study the effect of having a tertiary degree on the employment prospects and access to skilled positions among second-generation minority members.

This article constitutes an important contribution to the debate. We use recent data: the French Labour Force Surveys (LFS) from 2013 to 2017 and the 2014 adhoc module. Furthermore, we focus on a variety of labour market outcomes such as activity, employment, occupation and perceived over-qualification to build a comprehensive picture of labour market insertion. We compare the situation in the labour market of both immigrants and descendants from earlier and more recent waves of immigration, while taking into account heterogeneity and diversity of both origins and gender. First, we describe and measure the gaps between majority and minority members - with controls for education and socioeconomic and contextual characteristics (or "ethnic penalties", to refer to Heath \& Cheung, 2007)-by groups of origin, generation and gender. Secondly, we focus on the factors affecting this disadvantage. In one hand, we examine whether the remaining gaps among immigrants can be explained by duration of stay in France, language skills, education (received in France or abroad), nationality, which, importantly, have been captured in the surveys which we are using. On the other hand, we test the impact of the possession of tertiary degrees among second-generation minority members.

\section{Data and Methodology}

This study uses data from the French Labour Force Survey (LFS), a nationally representative dataset, gathered by the French National Institute of Statistics and Economic Studies (INSEE). A pooled sample has been built from 2013 to 2017, using data from the four quarters of each year, and the two first quarters of 2017. This provides rich and recent data on labour market outcomes which allows us to distinguish between the majority population, migrants and minorities. Moreover, generation and country of origin differences have been recorded. Additionally, we use the 2014 adhoc module that contains important information on immigrant's outcomes. The sample of this survey is too small for detailed generational analysis.

Our analysis is focused on respondents aged 18 to 64. Students, people in adult education or in training are excluded. We compare the labour market outcomes of migrants and second generation minorities to the outcomes of the majority group in France, differentiating between men and women. France here concerns Metropolitan France, our sample consisting of 595,214 men and 630,440 women-and among the active, re-

\footnotetext{
${ }^{1}$ According to the assimilation perspective, over time and generation, ethnic differences would be reduced (Alba \& Nee, 2003). According to the segmented assimilation perspective, changes in the labor market context and the racialization of contemporary migrants would reduce opportunities for social mobility that were afforded to European immigrants. The second generation might experience high levels of discrimination and downward assimilation (Portes \& Rumbaut, 2001; Portes \& Zhou, 1993).
} 
spectively, 491,318 men and 467,133 women. We excluded those with missing data on diploma $(N=2723)$ because this is a key variable for our study.

The origin variable is based on the respondents' place of birth, their parent's country of birth and nationality at birth. Individuals born outside France and foreign at birth are defined as immigrants. The second generation is defined as those born in France with at least one immigrant parent. The reference group, the majority population, includes individuals born in France whose parents are French at birth and born in France. We retain seven countries or areas of origins; for each, we distinguish first (born abroad) and second generations (born in France): EU15 and EU13 countries, Maghreb (Algeria, Morocco, Tunisia), Other Africa (or SubsaharanAfrica), Turkey, South-East Asia (Vietnam, Laos, Cambodia, China) and Other Asia. Among Europeans we distinguish between those from EU15 members (without France) and those from EU13 countries, the new EU members from East countries. The last category, with "other countries", is included in the analyses, but we don't present the outcomes on account of its heterogeneity. Table A1 in Annex presents the sample sizes by origin groups.

We focus on four outcomes: the probability of being employed (rather than unemployed or inactive, an indicator which measures the labour market participation and share of inactivity), ${ }^{2}$ the probability of being employed (rather than unemployed) among the active, as well as the probability of holding managerial and professional positions. This indicator is based on the current job occupation of the respondent, and ISCO-08 categories are used to measure highly-skilled jobs. Additionally, among immigrants, we analyse the probability of assessing oneself as overqualified; this subjective question on overqualification, in considering its own qualifications and skills, is only available in the adhoc module.

To give an overview of the employment patterns by generation status, country of origin and by gender (see Section 3.1), we first look at descriptive statistics to examine gross differentials (in percentages). All descriptive analyses are weighted. We then use multivariate analysis to measure the ethnic gaps (net of controls) for each labour market indicator (see Section 3.2).

Multivariate analyses are conducted separately by gender and introduce controls for factors that can explain the gaps: age, age squared, family situation activity and partner's activity (whether respondents have a partner or not and whether the partner is employed, unemployed or inactive), the number of children (no child, one, two or more), education measured by the highest diploma, self-reported health, place of residence, and the year of survey. Regarding education we distinguish between no diploma, vocational diploma-in lower secondary education-baccalaureate-high school diploma or equivalent-post-secondary degree-two-year de- gree after the baccalaureate-and more; on place of residence we distinguish whether they live in "zus", segregated areas-which have been shown to affect employment-in Paris or outside Paris. Through logistic regressions we estimate differences in the probability of employment (first for all individuals and then for the active), of accessing skilled jobs and of feeling overqualified. We report average marginal effects in the tables.

We use different analyses for migrants (see Section 3.3.1) and second generations (Section 3.3.2) to test specific hypotheses. For immigrants, based on the adhoc module, we include men and women and add gender as a control. We further include an indicator of nationality (foreign/French), duration of stay in France, linguistic skills or French knowledge (fluent French or mother tongue, difficulties with written or spoken French). In Table 3, we report the odds ratios from the logistic regression for some dependent variables, as we are mainly interested in the effect of ethnic origins, education and the factors linked to migration. Then, we investigate whether higher educational qualifications benefit migrants and whether having obtained any post-secondary degree in France or not ameliorates the prospects of immigrants in line with the human capital framework.

For the analysis focused on second generations compared to the majority, based on the LFS Surveys, we estimate whether higher education benefits the second generation. We include an interaction term between origin groups and highest diploma in order to compare the highly educated - those with a tertiary degree-and the lower educated-those with at most a secondary diploma. We report results as the difference in predicted probabilities for each outcome and minority group compared to similarly qualified majority member workers, estimated at the grand margin. We would expect lower ethnic gaps.

\section{Findings}

\subsection{An Overview of Employment Patterns by Generation, Groups of Origins and Gender}

Minorities individuals and the majority population differ in terms of individual and socio-demographic characteristics such as age, level of education, number of children, place of residence, etc. In particular, age structure varies a lot between different migrant groups. Second generation minority members are younger on average than the majority population though this pattern differs by origin. The proportion of people under 30 is particularly high among individuals with Turkish descent (59\%), from other Asian countries (55\%) and Other African countries (54\%), which constitute more recent waves of migration. This rate is lower for descendants from EU15 countries $(16 \%)$, which represent earlier waves of migration (the mean age for the latter is similar to those of the majority

\footnotetext{
2 This is the International Labour Organization's definition: active people include all persons who have been in paid employment during a reference week, just prior to the date of survey.
} 
population, at $17 \%) .^{3}$ It's interesting to analyse the situation in the labour market of groups from more recent waves of migration, less known, because they were too young in previous surveys and they are now numerous in the labour market.

The level of education varies largely between the origin groups and by generation. They live in different contexts: some groups, such as minorities from Maghreb and Sub-Saharan Africa live more in segregated areas than the majority members (between $17 \%$ and $26 \%$ versus $3 \%$ for the majority population in our data).

Table 1 distinguishes labour market outcomes by gender and generation. There are clear differences between men and women by generation in respect to inactivity. Here, employment rate is defined as the percentage of persons employed rather unemployed or inactive. Overall, the employment rate is lower for first- and secondgeneration minority members compared to the majority population, with large differences by country of origin.

Among men, employment is high and similar to that of the majority population of the second generations from EU15 countries and minorities from South-East Asia. In contrast, the second generations from EU13 countries and from Maghreb, as well as minorities (both generations) from Turkey and Sub-Saharan-Africa, are less likely to be employed. For the active, the picture changes a little; in particular, the second generation from EU15 and EU13 members catch up with majority members, while the employment rate remains low for minority members from Africa and Turkey. Surprisingly, for some groups, such as South-East Asians, Sub-Saharan-Africans and Turks, immigrants are more likely to be employed than the descendants of immigrants.

Among women, we observe huge differences between generations for some groups. While the employment rate appears very high for second-generation women from EU15 countries and close to that of the majority population; it is much lower for those coming from EU13 countries, Maghreb, Sub-Saharan Africa and Turkey, with significant differences between generations. Hence, only $24.5 \%$ of first-generation Turkish women are employed and more than $50 \%$ are inactive (66\%). In comparison, $44 \%$ of their descendants are employed, which is still low, but an increase across generations has been observed. Among North Africans, the employment rate goes from $35 \%$ to $60 \%$ (respectively from $46.5 \%$ to $74 \%$ for Other Asians) across generations. Low participation in the labour market is particularly widespread among women coming from Muslim countries. This reflects different cultural attitudes and relationships to the activity in the country of origin (these factors cannot be observed in this survey). Hence, the change across genera-

Table 1. Labour market outcomes by country of origin, generation and by gender (in \%). Source: INSEE Labour Force Survey 2013-2017, excluding people in education or in training.

\begin{tabular}{|c|c|c|c|c|c|c|c|}
\hline & & \multicolumn{3}{|c|}{ Men } & \multicolumn{3}{|c|}{ Women } \\
\hline & & Employed & $\begin{array}{c}\text { Employed } \\
\text { among } \\
\text { active }\end{array}$ & $\begin{array}{c}\text { Occupation } \\
\text { High skilled } \\
\text { jobs }\end{array}$ & Employed & $\begin{array}{l}\text { Employed } \\
\text { among } \\
\text { active }\end{array}$ & $\begin{array}{c}\text { Occupation } \\
\text { High skilled } \\
\text { jobs }\end{array}$ \\
\hline Majority & & 77,1 & 91,6 & 24,1 & 71,1 & 91,9 & 22,1 \\
\hline \multirow[t]{2}{*}{ EU15 } & $1 s t$ & 73,4 & 92,1 & 21,3 & 66,9 & 91,9 & 18,7 \\
\hline & 2nd & 77,2 & 91,3 & 21,5 & 70,8 & 91,4 & 19,3 \\
\hline \multirow[t]{2}{*}{ EU13 } & $1 s t$ & 74,0 & 84,3 & 20,3 & 60,4 & 84,1 & 25,4 \\
\hline & 2nd & 63,4 & 91,3 & 32,1 & 57,5 & 93,0 & 25,1 \\
\hline \multirow[t]{2}{*}{ Maghreb } & 1st & 62,3 & 76,3 & 13,0 & 35,4 & 75,8 & 10,3 \\
\hline & 2nd & 65,3 & 75,9 & 14,9 & 59,6 & 81,3 & 15,1 \\
\hline Other & $1 s t$ & 71,3 & 81,0 & 13,2 & 57,0 & 79,8 & 6,5 \\
\hline Africa & 2nd & 65,6 & 77,1 & 14,2 & 59,6 & 77,2 & 13,9 \\
\hline \multirow[t]{2}{*}{ Turkey } & $1 s t$ & 65,7 & 79,4 & 4,5 & 24,5 & 71,4 & 2,4 \\
\hline & 2nd & 64,8 & 74,5 & 7,5 & 43,9 & 74,0 & 5,3 \\
\hline SouthEast & $1 s t$ & 78,4 & 91,4 & 27,1 & 64,9 & 90,1 & 19,4 \\
\hline Asia & 2nd & 77,3 & 85,6 & 29,4 & 75,6 & 90,8 & 32,6 \\
\hline \multirow[t]{2}{*}{ Other Asia } & $1 s t$ & 75,3 & 86,7 & 28,1 & 46,5 & 84,2 & 20,0 \\
\hline & $2 n d$ & 72,7 & 85,0 & 33,4 & 74,3 & 89,3 & 35,1 \\
\hline
\end{tabular}

\footnotetext{
3 Immigration from Spain and Italy were earlier waves of immigration in the 1930s and, later, from Portugal, since 1970 . Immigration from Algeria after the Second World War and from Morocco, from the late 1960s, constitute regular flows. Since the 1960s, immigration concerns more African countries (out of Maghreb) and Asian countries, through the flows are less important.
} 
tions is particularly striking: the employment rate of the second generation surpasses the one of the first generation, except for the EU13 countries. Overall, second generations tend to adopt the model of the majority population. Among the active, the differences in employment between generations are smaller.

In terms of access to skilled jobs, access to a managerial or professional position varies largely by generation and origin groups.

Among men, Asian minorities and the EU13 second generations have the highest occupational attainment (between $27 \%$ and $33 \%$ ), exceeding that of majority members (24\%) while North-African and Sub-Saharan African origins have poor attainment. This lagging behind holds in both the first and second generations of North African descent. Among Europeans, outcomes differ more for occupation than for employment. While men from EU15 countries have a high employment rate, they are less likely to hold skilled jobs. The second generations from EU13 countries is more likely to access good position than the first generations, indicating a polarization within this group.

Among women, we note a progress from one generation to the other, with a higher proportion of skilled workers among the descendants of immigrants for almost all the origin groups. Skilled workers are particularly numerous among Asian second generation women (who surpass the first one and the majority population to reach more than $30 \%$ with very good occupational attainment). Yet, they are very few women in the Turkish origin group with good positions (respectively, 2.4 and 5.3\% for first and second generation).

The percentage of high skilled workers has increased over time, with the evolution of educational attainment, both in the countries of origins and in the host country. However, levels of education differ largely by origin group, generation and by gender (see Table A2 in Annex). First, we highlight a large progress from the first generation to the second one for almost all groups, except for the women from EU13 countries. The progress is huge in particular for women of Maghrebian, Sub-Saharan Africa and Turkish origin; the change between generations is even more pronounced when we include the inactive. However, the rate of higher educated remains quite low for the Turkish second generation (for both genders), while it appears particularly high among Asian secondgeneration men and women, ${ }^{4}$ who even surpass the majority population. This is consistent with previous French research that highlights the success in school careers of the South-East Asian second generation, and the low educational attainment of second generation Turks (Brinbaum \& Primon, 2013a). These results reflect also differences in social origins by ethnic groups, linked to the selectivity of migration (Feliciano, 2006) and the predominant role of social background for explaining the differences in educational attainment between the second generation and the majority population (Heath \& Brinbaum, 2007).

The trend is starkly different among men, as the share of highly educated is lower among Maghrebians and Sub-Saharan African second generation, and even lower for the descendant of Turks. This can be explained by the lower school careers of men and the fact that men were more likely to get vocational diplomas than women. It also reflects the huge proportion of people without diploma which can be responsible for their labour market difficulties.

\subsection{Multivariate Analysis: Measuring the Gaps in Employment and Occupation}

These differences can be related to the structural differences between the majority population and minorities, in terms of individual and socio-demographic characteristics (such as age, level of education, family situation, number of children and place of residence). All these factors have an impact on labour market outcomes, as it has been shown in previous research. Therefore, we use logistic regressions to measure the gaps and disentangle the effects of origins, once controlling for sociodemographic characteristics, education and place of residence (see Section 2 on methodology). Table 2 focuses on these gaps. Some large negative associations have been observed, indicating ethnic penalties, both in employment and occupation, for first and second generation men and women. We furthermore observe important differences between groups.

Among men, once controlling for compositional differences, the gaps (to the majority population) are reduced but remains negative for all groups, except for Europeans from EU15 countries and for South-East Asian second generation. The gaps are huge for some groups, e.g., individuals from African countries and immigrants from new EU member states, EU13 immigrants, and furthermore among Turkish immigrants. For most groups there is a reduction of the gap except for the Maghrebians, Asians and, to a lesser extent, for SubSaharan-Africans, for whom the gaps are similar for both generations.

Among women, as noticed previously, the gaps are particularly high in the first generation and reflect the lower labour market participation of new EU members (EU13) and some non-European groups, even controlling for socio-demographic characteristics. The gaps have diminished with the control of education in the model but remain large for the first generations (19.7 points for EU13; 30 points for Maghreb; 34.6 for Other Asia; 41.6 points for Turks). The second generation of these groups is still penalized compared to the majority population, except for the descendants of Southeast Asian.

Among the active, the trend is quite similar for men with a reduction of a few points, but the picture dif-

\footnotetext{
${ }^{4}$ Among Asians, we highlight a polarization among the first generation, with a group of lower educated and a large group of higher educated, while there is a high proportion of higher educated people among migrants from other Asian countries.
} 
Table 2. Estimated gaps in labour market outcomes from Majority population by gender. Source: INSEE Labour Force Survey 2013-2017, excluding people in education or in training.

\begin{tabular}{|c|c|c|c|c|c|c|c|}
\hline & & \multicolumn{3}{|c|}{ Men } & \multicolumn{3}{|c|}{ Women } \\
\hline & & $\begin{array}{l}\text { Probability to } \\
\text { be employed }\end{array}$ & $\begin{array}{l}\text { Probability to } \\
\text { be employed } \\
\text { among active }\end{array}$ & $\begin{array}{l}\text { Probability } \\
\text { to hold high } \\
\text { skilled jobs }\end{array}$ & $\begin{array}{c}\text { Probability } \\
\text { to be } \\
\text { employed }\end{array}$ & $\begin{array}{l}\text { Probability to } \\
\text { be employed } \\
\text { among active }\end{array}$ & $\begin{array}{c}\text { Probability to } \\
\text { hold high } \\
\text { skilled jobs }\end{array}$ \\
\hline & & M1 & M2 & M3 & M1 & M2 & M3 \\
\hline Ref. Majority & & Coef/SE & Coef/SE & Coef/SE & Coef/SE & Coef/SE & Coef/SE \\
\hline \multirow[t]{4}{*}{ EU15 } & $1 s t$ & 0,004 & $-0,005^{* *}$ & $-0,036 * * *$ & $-0,010 * * *$ & $-0,008 * * *$ & $-0,024 * * *$ \\
\hline & & 0,003 & 0,002 & 0,003 & 0,004 & 0,002 & 0,003 \\
\hline & $2 n d$ & $-0,004^{*}$ & $-0,002$ & 0,002 & $-0,013 * * *$ & $-0,005 * * *$ & $-0,011^{* * *}$ \\
\hline & & 0,003 & 0,002 & 0,003 & 0,003 & 0,002 & 0,002 \\
\hline \multirow[t]{4}{*}{ EU13 } & $1 s t$ & $-0,097 * * *$ & $-0,063 * * *$ & $-0,056 * * *$ & $-0,197 * * *$ & $-0,077^{* * *}$ & $-0,060 * * *$ \\
\hline & & 0,012 & 0,008 & 0,007 & 0,011 & 0,008 & 0,003 \\
\hline & $2 n d$ & $-0,032 * * *$ & $-0,011^{*}$ & $0,019 * *$ & $-0,023 * * *$ & 0,002 & $-0,001$ \\
\hline & & 0,008 & 0,006 & 0,009 & 0,009 & 0,006 & 0,007 \\
\hline \multirow[t]{4}{*}{ Maghreb } & $1 s t$ & $-0,142 * * *$ & $-0,107 * * *$ & $-0,092 * * *$ & $-0,303 * * *$ & $-0,105^{* * *}$ & $-0,069 * * *$ \\
\hline & & 0,004 & 0,003 & 0,002 & 0,004 & 0,004 & 0,002 \\
\hline & $2 n d$ & $-0,144 * * *$ & $-0,076 * * *$ & $-0,037 * * *$ & $-0,147 * * *$ & $-0,047^{* * *}$ & $-0,030 * * *$ \\
\hline & & 0,004 & 0,003 & 0,003 & 0,004 & 0,003 & 0,002 \\
\hline \multirow[t]{4}{*}{ Other Africa } & $1 s t$ & $-0,105^{* * *}$ & $-0,076 * * *$ & $-0,103 * * *$ & $-0,125 * * *$ & $-0,068 * * *$ & $-0,082 * * *$ \\
\hline & & 0,006 & 0,004 & 0,002 & 0,005 & 0,004 & 0,002 \\
\hline & $2 n d$ & $-0,092 * * *$ & $-0,038 * * *$ & $-0,029 * * *$ & $-0,080 * * *$ & $-0,040 * * *$ & $-0,037 * * *$ \\
\hline & & 0,009 & 0,005 & 0,007 & 0,010 & 0,005 & 0,005 \\
\hline \multirow[t]{4}{*}{ Turkey } & $1 s t$ & $-0,085 * * *$ & $-0,054 * * *$ & $-0,091 * * *$ & $-0,416 * * *$ & $-0,098 * * *$ & $-0,091 * * *$ \\
\hline & & 0,008 & 0,005 & 0,005 & 0,009 & 0,010 & 0,004 \\
\hline & $2 n d$ & $-0,037 * * *$ & $-0,019 * * *$ & $-0,034 * *$ & $-0,205 * * *$ & $-0,042 * * *$ & $-0,060 * * *$ \\
\hline & & 0,011 & 0,005 & 0,015 & 0,015 & 0,008 & 0,008 \\
\hline \multirow[t]{4}{*}{ SouthEast Asia } & $1 s t$ & $0,025^{* * *}$ & $-0,018^{* * *}$ & $-0,040 * * *$ & $-0,089 * * *$ & $-0,026 * * *$ & $-0,059 * * *$ \\
\hline & & 0,009 & 0,007 & 0,007 & 0,011 & 0,007 & 0,004 \\
\hline & 2nd & $-0,068$ & $-0,028 * * *$ & $0,022 *$ & 0,014 & $0,012 * *$ & $0,022 * *$ \\
\hline & & 0,014 & 0,008 & 0,013 & 0,014 & 0,006 & 0,010 \\
\hline \multirow[t]{4}{*}{ Other Asia } & 1st & $-0,047 * * *$ & $-0,049 * * *$ & $-0,066 * * *$ & $-0,346 * * *$ & $-0,089 * * *$ & $-0,072 * * *$ \\
\hline & & 0,009 & 0,006 & 0,005 & 0,009 & 0,009 & 0,003 \\
\hline & $2 n d$ & $-0,069 * * *$ & $-0,013$ & 0,012 & $-0,053 * *$ & $-0,019 *$ & $-0,011$ \\
\hline & & 0,019 & 0,009 & 0,016 & 0,022 & 0,010 & 0,010 \\
\hline
\end{tabular}

Notes: $* * * p<0.01, * * p<0.05, * p<0.1$. Estimated gap in the predicted probability of being employed (for all and among active) or accessing professional and managerial positions compared to the majority population, from logistic regression controlling for age (squared), family situation, education, year of survey, place of residence and health. Marginal effects are reported.

fers for women. The immigrants' gaps are considerably reduced compared to the first model. However, ethnic penalties in employment are observed for all immigrant men and women. We observe minor gaps for EU15 members and South-East Asians and larger gaps for EU13, Maghrebian and Sub-Saharan African groups, and to a lesser extent for Turks and other Asians (lower gaps in any case for men than for women).

We also observe a decrease of the gaps across generations. Nevertheless, the ethnic penalties remain significant however for the North-African, Sub-Saharan African and Turkish second generation men and women, and for South-East Asians (only for men, a positive associa- tion is observed among women). There is no difference (or little difference, less than 1 point) between the majority population and European or Asian second generation individuals.

In terms of occupational attainment, we observe disadvantages in access to high skilled occupations for all migrants, men and women. Again, we highlight important changes across generations, with a notable reduction of the gap between first and second generation individuals (Table 2, M3). However, ethnic penalties persist for both gender among the descendants of North African, Sub-Saharan African immigrants ( 2 to 4 points) and Turks (almost 6 points for women). Slight advantages are ob- 
served for South-East Asian second generations and the men of EU13 origins.

Comparing results across both outcomes show higher gaps in employment than in occupation for the North-African second generation (with larger differences for men), while there are higher gaps in occupation than in employment for the Turkish second generation (with larger differences for women). The picture is different for Europeans or Asian individuals, with little negative gaps in employment that become even positive when attaining a high skilled position is considered. These patterns hold for both SE Asian second generation men and women. Slight advantages are also observed for the second generation EU13 men.

Other factors play a role in employment and occupation. In all models (Table 2), tertiary degrees have the highest effect on the probability of employment and having a high skilled position. Hence, people without qualifications have significantly less chance to be employed and logically to access high skilled positions, while Tertiary educated individuals have better prospects (even higher when they got more than a bachelor's degree). Moreover, place of residence is an important factor. Living in a segregated area, where minorities are numerous, decreases both the employment probability and access to skilled positions of minority individuals. This can be due to spatial mismatch-that is to say economic deprivation can have a debilitating effect among individuals of different groups. More longitudinal research is needed for this pattern to be disambiguated.

\subsection{Mechanisms and Factors Explaining the Gaps}

\subsubsection{Returns of Foreign Educational Qualifications and} Role of Language Skills for Immigrants

Among immigrants, disadvantages remain for most of the groups in both employment and occupation. However, the difference from majority members can be explained by human capital and other factors related to the experience of migration, such as duration of stay in France, nationality, the problem of recognition of qualifications, language skills and more (Chiswick \& Miller, 2014), as well as the lack of knowledge of the functioning of the French labour market and lack of suitable networks. Do these factors explain the observed gaps? To answer this question, we use additional analyses focusing on immigrants, and using the 2014 adhoc module which contains some important variables, rarely present in other surveys. We take advantage of this data, despite its limitations to improve the understanding of the mechanisms leading to labour market in- tegration. As these factors do not relate to the majority members, we look at the associations of these variables with labour market outcomes among migrants with a new reference group: the first generation of European immigrants (from EU15). ${ }^{5}$

Table A3 in the Annex gives us some descriptive statistics by origin group and Table 3 reports the odds of the three regressions for the probability of being employed among the active, of having access to skilled jobs and of feeling overqualified for the current job. For each indicator, we control for the same variables as in Table 2, and add nationality, French knowledge, duration of stay in France, and a combined variable, which indicates whether the individual has a tertiary degree, and whether this is foreign or French qualification (instead of the detailed education variable-based on the highest diploma used in Table 2).

Table 3 M1 shows that all groups are still disadvantaged in terms of employment compared to EU15 immigrants with similar characteristics, even with the control of these additional variables.

While difficulties in speaking or writing in French decrease a little the probability of being employed-and this factor appeared significant once we control for the duration of stay in France, difficulties in both (oral and writing) have no significant effect. Besides, obtaining a tertiary degree in France or outside France does not affect the probability of employment. ${ }^{6}$ These outcomes, surprising at first insight, could be explained by the fact that migrants mobilize their social capital and use their personal networks to find a job. This is even more pronounced when French knowledge is low (48\% for those who encounter difficulties in speaking or writing found employment through networks, against $28 \%$ for those with a good level of French). This trend varies a lot by country of origin: hence, $57 \%$ of immigrants from EU15 countries found their current job by deploying diverse networks (mostly family and personal networks; see Table A3 in Annex). Networks are also very efficient for migrants from Turkey (51\%) despite of their lower educational attainment, even more than for the majority population (34\%). This can foster access to employment, however there is a little or no impact on the access to skilled jobs. $^{7}$

Furthermore, having foreign nationality decreases the probability of employment, insofar that it prevents access to certain jobs (those of public sector) and limits access to jobs due to administrative restrictions (Fougère \& Safi, 2005). This effect disappears in access to skilled jobs and as to perceived overqualification.

Even though French knowledge has little effect on the probability of employment, it has a stronger impact

\footnotetext{
${ }^{5}$ The EU13 category, too small in the adhoc module, has been gathered with the category of other origins, as well as immigrant from Asian countries in another category.

${ }^{6}$ However, when we exclude the knowledge of French in the model, qualifications obtained in France has a positive effect on employment, while this is not the case with tertiary degree obtained abroad. A previous model, with a detailed highest diploma, highlights the positive effect of the higher levels of tertiary degree (more than three years after the baccalaureate) on employment.

${ }^{7}$ Channel of getting a job has been added as explanatory variable to the M2. Finding a job through networks (rather than spontaneous application) increases the access to skilled jobs for men, but not for women.
} 
Table 3. Logistic regressions on labour market outcomes among immigrants (odds ratios). Source: INSEE Labour Force Survey $2014 \S$ adhoc module.

\begin{tabular}{|c|c|c|c|c|c|c|}
\hline & \multicolumn{2}{|c|}{$\begin{array}{l}\text { Probability to be } \\
\text { employed (M1) }\end{array}$} & \multicolumn{2}{|c|}{$\begin{array}{l}\text { Probability to hold } \\
\text { skilled jobs (M2) }\end{array}$} & \multicolumn{2}{|c|}{$\begin{array}{l}\text { Probability to feel } \\
\text { overqualified (M3) }\end{array}$} \\
\hline & Odds & SE & Odds & SE & Odds & SE \\
\hline \multicolumn{7}{|l|}{ Ref. EU15 } \\
\hline Maghreb & $0,26 * * *$ & 0,29 & $0,24 * * *$ & 0,34 & $2,03 * * *$ & 0,24 \\
\hline Oher Africa & $0,24 * * *$ & 0,26 & $0,32 * * *$ & 0,31 & $2,20 * * *$ & 0,21 \\
\hline Turkey & $0,26 * * *$ & 0,36 & $0,19 * *$ & 0,81 & 1,16 & 0,38 \\
\hline Asia $0,34 * * *$ & 0,36 & 0,58 & 0,39 & 1,54 & 0,30 & \\
\hline Others & $0,37 * * *$ & 0,30 & $0.53^{* *}$ & 0,31 & $1,59 *$ & 0,24 \\
\hline Women/Men & 0,78 & 0,16 & $0,60 * *$ & 0,20 & 1,00 & 0,14 \\
\hline \multicolumn{7}{|l|}{ Ref. Below } \\
\hline Tertiary degree: in France & 1.35 & 0,24 & $25,91 * * *$ & 5,15 & $1,55^{* *}$ & 0,20 \\
\hline outside France & 0,88 & 0,22 & $11,53 * * *$ & 2,47 & $2,33 * * *$ & 0,21 \\
\hline \multicolumn{7}{|l|}{ Nationality: Ref. French } \\
\hline Foreign & $0.62 * * *$ & 0,17 & 0,88 & 0,25 & 1,3 & 0,16 \\
\hline \multicolumn{7}{|c|}{ Ref. Perfect French or mother tongue } \\
\hline Difficulties at oral or writing & $0,65^{* *}$ & 0,21 & $0,30 * * *$ & 0,32 & $1,48^{* *}$ & 0,19 \\
\hline Difficulties at oral and writing & 0,72 & 0,21 & $0,27 * * *$ & 0,33 & $1,45^{* * *}$ & 0,19 \\
\hline
\end{tabular}

Notes: ${ }^{* *} \mathrm{p}<0.01,{ }^{* *} \mathrm{p}<0.05,{ }^{*} \mathrm{p}<0.1$. Field: immigrants (18 to 64 ), active (M1) and employed (M2, M3). Controls for age, age2, number of children, place of residence, partner's activity, duration of stay in France.

on access to skilled jobs and feeling of over-qualification. Hence, language skills have a significant effect on the probability of accessing managerial and professional positions (once controlling for educational attainment and socio-demographic characteristics). Migrants with difficulties in French have less chance to gain such positions. Taking into account the strong relationship between diploma and occupation in France, access to these positions gradually increases with the level of education. However, among the Tertiary degree holders, those who obtained their degree abroad (rather than in France) have lower chances of access to these positions. It is difficult to analyse the gaps further with the data, but the patterns observed seem to reflect a lack of human capital and of degree recognition, as well as quality of education-among immigrants who would have liked to have their foreign diploma recognized when they arrived in France, almost a third said that they did not succeed. This is a problem particularly encountered by migrants from less developed countries. A long duration in France (more than 15 years) is positively correlated with access to skilled jobs. Moreover, women are less likely to hold skilled positions compared to men with similar qualifications and characteristics.

Somewhat similar trends emerge for perceived overqualification. Descriptive statistics (in Table A3 in Annex) show that migrants from all groups feel more overqualified than the majority population (16\%): almost a quarter of Europeans (EU15) and Asians, 29\% of Turkish and $35 \%$ of migrants from Maghreb and Sub-Saharan Africa express this feeling. Table $3 \mathrm{M} 3$ shows that compared to
Europeans (EU15), the effect of ethnic origins remains significant for perceived overqualification for two groups, the North Africans and Sub-Saharan Africans, the groups who also appear most disadvantaged in access to employment and high skilled occupations. The more educated workers are more likely to express this feeling, but this is amplified when they gained their degree abroad (odds $=2.3$ ). Furthermore, those who have difficulties in French feel more overqualified.

Hence, lack of human capital, through lack of French proficiency or lack of French tertiary qualifications has a significant impact on access to skilled jobs and perceived over-qualification. These results have been observed as to immigrants' wages (Bechichi, Bouvier, Brinbaum, \& Lê, 2016). These additional variables explain labour market disadvantages between EU15 migrants and other migrants, though we need further research, with larger samples to disentangle the effect of different factors. Returns to human capital are related to the quality of education, recognition of diplomas and skills in the host country, which is difficult to measure in the LFS. However, ethnic penalties remain and may be attributed to other factors - not measurable in the survey-and discrimination, in line with previous research (see the discussion in Section 3.3.3).

\subsubsection{Returns to Higher Education for Second Generations}

Table 4 compares the ethnic gaps for the highly educated (with a tertiary degree) and the lower educated (at most 
Table 4. Estimated gaps of having post-secondary education (rather than below*) on labour market outcomes for second generation by origin groups and gender. Source: INSEE Labour Force Survey 2013-2017.

\begin{tabular}{|c|c|c|c|c|c|}
\hline & & \multicolumn{2}{|c|}{ Men } & \multicolumn{2}{|c|}{ Women } \\
\hline & & $\begin{array}{l}\text { Probability to be } \\
\text { employed }\end{array}$ & $\begin{array}{l}\text { Probability to hold } \\
\text { high skilled jobs }\end{array}$ & $\begin{array}{l}\text { Probability to be } \\
\text { employed }\end{array}$ & $\begin{array}{l}\text { Probability to hold } \\
\text { high skilled jobs }\end{array}$ \\
\hline \multicolumn{2}{|l|}{ Ref. Majority } & Coef/SE & Coef/SE & Coef/SE & Coef/SE \\
\hline \multirow[t]{4}{*}{ EU15 } & Below & $-0,004 *$ & $0,007 * * *$ & $-0,005^{* *}$ & 0,001 \\
\hline & & 0,002 & 0,002 & 0,002 & 0,002 \\
\hline & tertiary degree & $-0,000$ & $-0,037 * * *$ & $-0,005^{* *}$ & $-0,041 * * *$ \\
\hline & & 0,002 & 0,007 & 0,002 & 0,006 \\
\hline \multirow[t]{4}{*}{ EU13 } & Below & $-0,013$ & 0,007 & 0,007 & 0,001 \\
\hline & & 0,008 & 0,007 & 0,008 & 0,005 \\
\hline & tertiary degree & $-0,005$ & $0,070 * * *$ & $-0,006$ & 0,151 \\
\hline & & 0,008 & 0,020 & 0,008 & 0,198 \\
\hline \multirow[t]{4}{*}{ Maghreb } & below & $-0,092 * * *$ & $-0,020 * * *$ & $-0,053^{* * *}$ & $-0,007 * * *$ \\
\hline & & 0,004 & 0,002 & 0,004 & 0,002 \\
\hline & tertiary degree & $-0,035 * * *$ & $-0,085^{* * *}$ & $-0,037 * * *$ & $-0,102 * * *$ \\
\hline & & 0,004 & 0,009 & 0,004 & 0,008 \\
\hline \multirow[t]{4}{*}{ Other Africa } & below & $-0,045^{* * *}$ & $-0,022 * * *$ & $-0,029 * * *$ & $-0,007$ \\
\hline & & 0,006 & 0,006 & 0,007 & 0,006 \\
\hline & tertiary degree & $-0,014 * *$ & $-0,066 * * *$ & $-0,047 * * *$ & $-0,131 * * *$ \\
\hline & & 0,007 & 0,020 & 0,007 & 0,016 \\
\hline \multirow[t]{4}{*}{ Turkey } & below & $-0,020 * * *$ & $-0,042 * * *$ & $-0,048 * * *$ & 0,001 \\
\hline & & 0,007 & 0,007 & 0,011 & 0,012 \\
\hline & tertiary degree & $-0,036 * * *$ & $-0,074^{*}$ & $-0,039 * * *$ & $-0,257 * * *$ \\
\hline & & 0,014 & 0,042 & 0,013 & 0,030 \\
\hline \multirow[t]{4}{*}{ South-East Asia } & below & $-0,023^{* *}$ & $0,033^{* *}$ & $0,039 * * *$ & $0,041^{* * *}$ \\
\hline & & 0,010 & 0,016 & 0,007 & 0,015 \\
\hline & tertiary degree & $-0,021 * *$ & $0,061 * * *$ & $-0,012$ & 0,030 \\
\hline & & 0,008 & 0.23 & 0,008 & 0,022 \\
\hline \multirow[t]{4}{*}{ Other Asia } & below & 0,007 & $0,096 * * *$ & 0,007 & $0,056 * *$ \\
\hline & & 0,011 & 0,029 & 0,015 & 0,012 \\
\hline & tertiary degree & $-0.024 * *$ & $-0,019$ & $-0,029 * * *$ & $-0,008$ \\
\hline & & 0.11 & 0,032 & 0,011 & 0,029 \\
\hline
\end{tabular}

Notes: ${ }^{* * *} \mathrm{p}<0.01,{ }^{* *} \mathrm{p}<0.05,{ }^{*} \mathrm{p}<0.1$. Field: $18-64$, excluding people in education or in training. Majority population and second generations. Results are explained as marginal effects. *Note: Below means at most, secondary diploma. Controls for age, age2, number of children, place of residence, partner's activity, year of survey.

secondary education) by adding interactions between educational attainment and origin groups. It allows us to measure whether a tertiary degree may reduce employment gaps between the majority population and the second generation.

Different patterns appear by groups of origins and by gender. A tertiary degree increases the chances of being employed (in reducing the gap without cancelling it) for the descendants of Maghreb, men and women, and Sub-Saharan African men. However, it even decreases the probability of employment (in enlarging the gaps) for the Sub-Saharan second generation women and the Turkish second generation men. Besides, no improvement is seen among South East Asian second generation men.
Hence, a tertiary degree brings better the access to the labour market for some groups, particularly among men belonging to minorities who are likely to experience discrimination, through the ethnic gaps do not vanish. However, a Tertiary degree does not have the expected effect on the labour market entry of other groups.

The returns to higher education are negative for obtaining high skilled positions for the North-African, Other African and Turkish second-generation individuals (and the gaps are reinforced among the women in these groups). In contrast, some advantage is observed for the South-East Asians second generation men.

For some groups, returns to higher education are positive and reduction in the gap between the majority pop- 
ulation and the second generation is observed, while for others, returns are even lower, particularly for accessing high skilled positions. This is an unexpected result that questions the opportunities of upward social mobility among the second generation.

However, for this thematic issue (and harmonization in comparative perspective), we use a rough category for the "higher educated" (individuals with a tertiary degree). Nevertheless, this category includes different degrees, from more or less selective programmes and diverse fields of study, at different levels, which have not the same value in the labour market. Previous research has shown unequal access and careers in higher education among the second generation linked to their social and migratory backgrounds and previous school careers. For instance, North-African second generation is more likely to get vocational or technological baccalaureate (as opposed to an academic one) that reduces access to selective tertiary programmes and success at university. Second generations have different routes into secondary and higher education which affects both degree completion and entry into the French labour market (Brinbaum \& Guégnard, 2013). This has an impact on the degree completed and therefore on labour market access and careers. Hence, a better consideration of the differences in higher education and factors fostering the labour market outcomes may reduce ethnic gaps.

\subsubsection{Further Explanations of Remaining Ethnic Gaps}

The remaining ethnic gaps in the labour market, in general and among the higher educated, reflect ethnic penalties that can be explained further (e.g., Heath \& Yu, 2005).

A potential explanation is the lack of networks for accessing a job (Granovetter, 1974) for some groups and the use of ethnic resources for others. The role of social networks in the professional integration of immigrants and ethnic minorities have been demonstrated in the United States, particularly in the Mexican community (Mundra \& Amuedo-Dorantes, 2004; Waldinger, 1994). The propensity for ethnic minorities to find more employment than majority members through ethnic networks is well-established (Fernandez \& Fernandez-Mateo, 2006). Similar patterns have been observed in France for the Portuguese community, explaining their high employment (Domingues Dos Santos, 2005) and confirmed for Portuguese and Turkish first and second generations based on the French Trajectories and Origins Survey (Brinbaum, 2018).

These trends are visible here with more recent data (Table A2 in Annex). Immigrants are more likely to get their jobs through networks than both the majority population ( $25 \%$ for men and $21.7 \%$ for women) and second generation individuals, with notable differences by origin and by gender. The share of networks in access to employment is particularly high among Europeans and Turkish migrants ( $43 \%$ and $38 \%$ for the men from EU13 and EU 15 countries, $35 \%$ and $30 \%$ for the women; and respectively, $52 \%$ and $43 \%$ for the Turkish men and women) and for Asian men to a lesser extent (35\% to $37 \%$ ). In contrast, these results reflect lack of networks among the women of North-African, other African and Turkish origins. They do not have efficient networks that can help them reach high skilled jobs. We can refer to Putnam (2000) who distinguishes between bridging and bonding social capital (Turks and South Europeans in particular would use more bonding capital among co-ethnics). Turkish men are also more numerous among the selfemployed in ethnic niches, and this can contribute to their high employment. However, they are less likely to hold skilled jobs.

The remaining ethnic gaps, higher for minorities from North Africa and Sub-Saharan Africa may be attributed to discrimination (direct and indirect discrimination). ${ }^{8} \mathrm{Ob}-$ served employment gaps are consistent with previous research and with the level of experience of discrimination these groups declare and can be attributed mainly to their racial and ethnic origins (Brinbaum, Safi, \& Simon, 2016) or to "religious cleavages" (Alba \& Foner, 2015). Discrimination in hiring against these groups have been confirmed by testing (Duguet, L'Horty, \& Petit, 2009; Petit, Duguet, L'Horty, Parquet, \& Sari, 2013). Discrimination may occur in hiring, but also in careers, leading to lower access to high skilled positions. Second generation women may be blocked by the "Glass ceiling" and by ethnic, racial and gender discrimination. Social and ethnic segregation also influence the labour outcomes. Living in segregated areas has also a negative effect on labour market employment. Investigating each of these issues in detail is beyond the scope of the present paper.

\section{Conclusions}

Based on recent data, the pooled 2013-2017 French LFS, we show large differences in the French labour market between minorities and the majority population by generation, country of origin and by gender. Like previous studies, we find evidence of stark ethnic disadvantage in the French labour market. We highlight the disadvantage for the first and second generation, for both men and women. Furthermore, differences appear between and within origin groups.

Ethnic penalties in employment and in access to skilled occupations are observed for all immigrants but their magnitude depends on ethnic origins. Lack of human capital explains to some extent migrants' labour market disadvantages, particularly French knowledge and educational qualification transferability are very important. These variables have however a greater impact on occupation and perceived overqualification than on employment. Furthermore, immigrants tend to mobilize more their social capital for finding a job.

A certain pattern emerges: disadvantages decline across generations, particularly for the second genera-

\footnotetext{
${ }^{8}$ Unexplained differences are also due to unobserved variables and other external factors.
} 
tion, socialized and educated in France. This reflects a real progress in employment and access to skilled occupations across generations, in line with the evolution of educational attainment. This trend is even more pronounced among women.

Despite this real improvement, our research confirms the persistence of ethnic inequalities in access to employment and high skilled positions for some groups: the male and female descendants of North-African and SubSaharan African origin and to a lesser extent for the Turkish second generation women. In contrast, Asian second generation men and women encounter even a slight advantage in attaining high skilled positions. Their high educational attainments are transferred into occupation.

The share of Tertiary degree holders has increased among the second generations, even more for women. However, ethnic gaps have not disappeared at this level. Some employment gaps are reduced, in particular among the descendants of Maghreb and Sub-Saharan Africa (men), who benefit from postsecondary education to a certain extent. Ethnic penalties remain and even increase for accessing skilled positions (particularly for women of the same origin). More highly educated than the first generations, yet second generation women have less access to highly skilled jobs. This limits upward social mobility. These outcomes may be linked to their post-secondary school experience, and differentiated pathways in higher education, lack of suitable networks and possible discrimination (linked to ethnic origins and gender). Further analyses will be investigated further in this respect.

\section{Acknowledgments}

This thematic issue has been supported by funding from the European Commission (Grant number H2020 649255).

\section{Conflict of Interests}

The author declares no conflict of interests.

\section{References}

Aeberhardt, R., Fougère, D., Pouget, J., \& Rathelot, R. (2010). L'emploi et les salaires des enfants d'immigrés [Employment and wages of the children of immigrants.] Economie et statistique, 433/434, 31-46.

Alba, R., \& Nee, V. (2003). Remaking the American mainstream: Assimilation and contemporary immigration. Cambridge: Harvard University Press.

Alba, R., \& Foner, N. (2015). Strangers no more: Immigration and the challenges of integration in North America and Western Europe. Princeton, NJ: Princeton University Press.

Beauchemin, C., Hamel, C., \& Simon, P. (Eds.). (2016). Trajectoires et origines: Enquête sur la diversité des pop- ulations. [Trajectories and origins: Survey on population diversity in France]. Paris: Ined.

Bechichi, N., Bouvier, G., Brinbaum, Y., \& Lê, J. (2016). Maîtrise de la langue et emploi des immigrés: Quels liens? [Language proficiency and employment of immigrants: what links?] Emploi, chômage, revenus du travail. Insee Références. Retrieved from www.insee. $\mathrm{fr} / \mathrm{fr} /$ statistiques $/ 2122739$ ?sommaire $=2122750$

Boumahdi, R., \& Giret, J. F. (2005). Une analyse économétrique des disparités d'accès à l'emploi et de rémunérations entre jeunes d'origine française et jeunes issus de l'immigration. [Econometrical analysis of differences in access to employment and wages between young people with French natives-born parents and those with immigrants backgrounds.] Revue économique, 56(3), 625-636.

Brinbaum, Y. (2018). L'accès à l'emploi des descendants d'immigrés en début de carrière: Le rôle clé des réseaux et des intermédiaires. [The access to employment of second generation youth in France: The major role of networks and labour market intermediaries.] Formation Emploi, 1(141), 193-212.

Brinbaum, Y., \& Guégnard, C. (2013). Choices and enrolments in French secondary and higher education: Repercussions for second-generation immigrants. Comparative Education Review, 57(3), 481-502.

Brinbaum, Y., \& Issehnane, Y. (2015). The early careers of the second generations: A double ethnic penalty? Training \& Employment, 2015(119), 4.

Brinbaum, Y., Meurs, D., \& Primon, J.-L. (2016). Situation sur le marché du travail: Statuts d'activité, accès à l'emploi et discrimination. [Labour market situation: Activity status, access to employment and discrimination.] In C. Beauchemin , C. Hamel, \& P. Simon (Eds.), Trajectoires et origines: Enquête sur la diversité des populations. Paris: Ined.

Brinbaum, Y., \& Primon, J. L. (2013a). Parcours scolaires et sentiment d'injustice et de discrimination chez les descendants d'immigrés. [School careers and feelings of injustice and discrimination among the descendants of immigrants]. Economie et statistique, 464/465/466, 215-243.

Brinbaum, Y., \& Primon, J. L. (2013b). Transition professionnelle et emploi des descendants d'immigrés en France. [School to work transition and employment among the descendants of immigrants in France]. Revue européenne des sciences sociales, 51(1), 33-63.

Brinbaum, Y., Safi, M., \& Simon, P. (2016). Les discriminations en France: Entre perception et expérience. [Discriminations in France: Between perception and experience]. In C. Beauchemin, C. Hamel, \& P. Simon (Eds.), Trajectoires et origines: Enquête sur la diversité des populations. Paris: Ined.

Brinbaum, Y., \& Werquin, P. (1997). Enfants d'immigrés: Un accès au travail difficile. Des itinéraires spécifiques. [Transitions into the labour markets of young people from immigrant families: Difficult access. Different pathways.] Informations Sociales, 62, 32-41. 
Brinbaum, Y., \& Werquin, P. (2004). Des parcours semés d'embûches: l'insertion professionnelle des jeunes d'origine maghrébine en France. [Obstacles in the transitions from school to work for North-African second-generation youth.] In L. Achy, J. de Henau, N. El Kadiri, K. Kateb, J. Laufer, C. Marry, M. Maruani (Eds.), Marché du travail et genre. Maghreb-Europe (pp. 145-166). Bruxelles: Dulbea.

Brutel, C. (2014). Les immigrés récemment arrivés en France [Immigrants recently arrived in France]. Insee Première 1524. Paris: INSEE. Retrieved from www.insee. $\mathrm{fr} / \mathrm{fr} /$ statistiques/1281393

Chiswick, B., \& Miller, P. (2014). International migration and the economics of language (IZA Discussion Papers 7880). Bonn: IZA.

Damas de Matos, A., \& Liebig, T. (2014). The qualifications of immigrants and their value in the labour market: A comparison of Europe and the United States. In OECD \& EU (Eds.), Matching economic migration with labour market needs (pp. 187-228). Paris: OECD Publishing.

Domingues Dos Santos, M. (2005). Travailleurs maghrébins et portugais en France: Le poids de l'origine. [North African and Portuguese workers in France.] Revue Economique, 56, 447-464.

Duguet, E., L'Horty, Y., \& Petit, P. (2009). L'apport du Testing à la mesure des discriminations. Connaissance de l'emploi, 2009(68).

Dupray, A., \& Moullet, S. (2004). L'insertion des jeunes d'origine maghrébine en France. Des différences plus marquées dans l'accès à l'emploi qu'en matière salariale [The insertion of young people of Maghreb origin in France. More differences in access to employment than in pay] (Document Net.Doc 6). Marseille: Céreq.

Feliciano, C. (2006). Unequal origins: Immigrant selection and the education of the second generation. New York, NY: LFB Scholarly Publishing.

Fernandez, R., \& Fernandez-Mateo, I. (2006). Networks, race and hiring. American Sociological Review, 71(1), 42-71.

Fougère, D., \& Safi, M. (2005). L'acquisition de la nationalité française: quels effets sur l'accès à l'emploi des immigrés? [The effects of naturalization on immigrants' employment probability?] In INSEE (Ed.), France, portrait social (pp. 163-184). Paris: INSEE.

Frickey, A., \& Primon, J. L. (2006). Une double pénalisation pour les non-diplômées du supérieur d'origine nord-africaine? [A double penalty for non-graduates of North African origin?] Formation Emploi, 2(94), 27-43.

Granovetter, M. (1974). Getting a job, a study of contacts and careers. Cambridge, MA: Harvard University Press.

Heath, A., \& Brinbaum, Y. (2007). Explaining ethnic inequalities in educational attainment. Ethnicities, $7(3)$,
291-304.

Heath, A., \& Cheung, S. Y. (2007). Unequal chances: Ethnic minorities in Western labour markets. In Proceedings of the British Academy (p. 732). Oxford: Oxford University Press.

Heath, A., \& Yu, S. (2005). Explaining ethnic minority disadvantage. In A. F. Heath, J. Ermisch, \& D. Gallie (Eds.), Understanding social change (pp. 187-225). Oxford: Oxford University Press.

Meurs, D., Pailhé, A., \& Simon, P. (2005). Immigrés et enfants d'immigrés sur le marché du travail: Une affaire de génération? [Immigrants and children of immigrants on the labor market: a generation's affair?] In C. Lefèvre \& A. Filhon (Eds.), Histoires de familles, histoires familiales (pp. 461-482). Paris: Ined.

Meurs, D., Pailhé, A., \& Simon, P. (2006). Mobilité entre générations d'immigration et persistance des inégalités: L'accès a' l'emploi des immigrés et leurs descendants en France [Mobility between generations of immigrants and persistence of inequalities]. Population, 61(5/6), 763-801.

Mundra, K., \& Amuedo-Dorantes, C. (2004). Social networks and their impact on the employment and earnings of mexican immigrants. SSRN, September. http://dx.doi.org/10.2139/ssrn.725918

Noiriel, G. (1988). Le creuset français. Histoire de I'immigration XIXe-XXe siècles. [The French crucible. History of immigration nineteenth and twentieth centuries.] Paris: Editions du Seuil.

Petit, P., Duguet, E., L'Horty, Y., du Parquet, L., \& Sari, F. (2013). Les effets du genre et de l'origine se cumulentils systématiquement? [Do the effects of gender and origin systematically cumulate?] Économie et Statistique, 464/465/466.

Portes, A., \& Rumbaut, R. (2001). Legacies: The story of the immigrant second generation. Berkeley, CA: University of California Press.

Portes, A., \& Zhou, M. (1993). The new second generation: Segmented assimilation and its variants. The Annals of the American Academy of Political Science, 503(November), 74-96.

Putnam, R. D. (2000). Bowling alone: The collapse and revival of American community. New York, NY: Simon \& Schuster.

Silberman, R., Alba, R., \& Fournier, I. (2007). Segmented assimilation in France? Discrimination in the labour market against the second generation. Ethnic and Racial Studies, 30(1), 1-27.

Silberman, R., \& Fournier, I. (1999). Les enfants d'immigrés sur le marché du travail. Les mécanismes d'une discrimination sélective. Formation Emploi, $65,31-55$.

Waldinger, R. (1994). The making of an immigrant niche. International Migration Review, 28(1), 3-30. 


\section{About the Author}

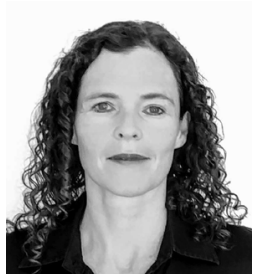

Yaël Brinbaum is an Associate Professor of Sociology at the CNAM in Paris, Senior Researcher at the LISE (UMR CNRS) and at the CEET. She conducts research on educational inequalities, transitions from school to work and labour market outcomes of ethnic minorities. She currently coordinates a project on access to employment, job quality and labour market trajectories of the second-generation youth in European countries and the United States. Her research interests include job search, role of networks and discrimination at school and in the labour market. She has been involved in numerous comparative projects and coordinated with Anthony Heath the book: Unequal Attainments: Ethnic Educational Inequalities in Ten Western Countries (Proceedings of the British Academy, 2014). 
Annex

Table A1. Sample sizes by origin groups and by generation (N). Source: INSEE Labour Force Survey 2013-2017, excluding people in education or in training.

\begin{tabular}{lcccc}
\hline & & All & Active & Employed \\
\hline Majority & & 994116 & 787512 & 723326 \\
\hline EU15 & 1st & 29941 & 22223 & 20462 \\
& 2nd & 55882 & 44179 & 40424 \\
\hline EU13 & 2nt & 4656 & 3612 & 3061 \\
& 1st & 5639 & 3531 & 3272 \\
\hline Maghreb & 2nd & 40202 & 25260 & 19258 \\
& 1st & 30981 & 24400 & 18979 \\
\hline Other Africa & 2nd & 18867 & 14770 & 41805 \\
& 1st & 5414 & 4472 & 3443 \\
\hline Turkey & 2nd & 6979 & 4073 & 3143 \\
& 1st & 2826 & 1983 & 1444 \\
\hline South-East Asia & 2nd & 4448 & 3415 & 3085 \\
& 1st & 2325 & 1961 & 1719 \\
\hline Other Asia & 2nd & 6072 & 4187 & 1053 \\
\end{tabular}

Note: unweighted Ns.

Table A2. Educational attainment of active and share of employees who got their current job through relations, by origin groups, generation and by gender (\%). Source: INSEE Labour Force Survey 2013-2017.

\begin{tabular}{|c|c|c|c|c|c|c|c|}
\hline & & \multicolumn{2}{|c|}{ Men } & \multicolumn{2}{|c|}{ Women } & Men & Women \\
\hline & & \multicolumn{4}{|c|}{ Educational attainment* } & & \\
\hline & & $\begin{array}{l}\text { Lower } \\
\text { educated }\end{array}$ & $\begin{array}{l}\text { Higher } \\
\text { educated }\end{array}$ & $\begin{array}{l}\text { Lower } \\
\text { educated }\end{array}$ & $\begin{array}{l}\text { Higher } \\
\text { educated }\end{array}$ & \multicolumn{2}{|c|}{$\begin{array}{l}\text { Share of people who got their } \\
\text { current job through relations** }\end{array}$} \\
\hline Majority & & 16,0 & 34,5 & 14,7 & 42,1 & 25,3 & 21,7 \\
\hline \multirow[t]{2}{*}{ EU15 } & $1 s t$ & 40,7 & 26,3 & 37,5 & 31,0 & 38,1 & 34,9 \\
\hline & $2 n d$ & 19,5 & 29,4 & 15,8 & 38,0 & 29,2 & 25,1 \\
\hline \multirow[t]{2}{*}{ EU13 } & $1 s t$ & 23,4 & 32,1 & 13,2 & 60,1 & 42,8 & 29,7 \\
\hline & 2nd & 13,3 & 37,3 & 23,1 & 39,6 & 26,3 & 25,4 \\
\hline \multirow[t]{2}{*}{ Maghreb } & $1 s t$ & 37,6 & 28,8 & 40,6 & 28,1 & 28,9 & 26,4 \\
\hline & $2 n d$ & 26,2 & 26,6 & 18,7 & 36,8 & 26,7 & 19,7 \\
\hline \multirow[t]{2}{*}{ Other Africa } & $1 s t$ & 34,6 & 33,6 & 39,9 & 24,6 & 30,5 & 27,2 \\
\hline & 2nd & 25,9 & 29,8 & 15,9 & 41,2 & 26,1 & 15,7 \\
\hline \multirow[t]{2}{*}{ Turkey } & $1 s t$ & 61,2 & 7,7 & 62,7 & 10,1 & 51,7 & 43,4 \\
\hline & 2nd & 39,3 & 18,3 & 20,2 & 26,9 & 37,4 & 18,1 \\
\hline \multirow[t]{2}{*}{ South-East Asia } & $1 s t$ & 36,9 & 37,1 & 37,2 & 39,9 & 35,0 & 33,3 \\
\hline & 2nd & 10,9 & 50,8 & 9,0 & 57,8 & 25,0 & 19,8 \\
\hline \multirow[t]{2}{*}{ Other Asia } & $1 s t$ & 30,8 & 42,3 & 28,1 & 51,1 & 37,1 & 27,7 \\
\hline & $2 n d$ & 8,8 & 56,8 & 4,0 & 71,7 & 17,0 & 21,4 \\
\hline
\end{tabular}

Notes: ${ }^{*}$ active excluding people in education or in training; ${ }^{* *}$ employees at the date of the survey. The question comes from the LFS survey about the access to the current job (firm). Lower educated corresponds to no diploma or less than a secondary diploma; Higher educated to a tertiary degree. 


\section{COGITATIO}

Table A3. Labour market outcomes for immigrants and the majority population in 2014 (in \%). Source: adhoc module (2014).

\begin{tabular}{|c|c|c|c|c|c|c|}
\hline & \multicolumn{4}{|c|}{ Share of people who found their current job through networks } & \multicolumn{2}{|c|}{ Labour market outcomes } \\
\hline & $\begin{array}{l}\text { Personal and } \\
\text { family relations }\end{array}$ & $\begin{array}{l}\text { Professional } \\
\text { relations }\end{array}$ & $\begin{array}{l}\text { Association of immigrants } \\
\text { or compatriots }\end{array}$ & Total & $\begin{array}{c}\text { Access to } \\
\text { high-skilled jobs }\end{array}$ & $\begin{array}{c}\text { Feeling of being } \\
\text { overqualified }\end{array}$ \\
\hline Majority & 21 & 13 & 0 & 34 & 21 & 16 \\
\hline EU15 & 44 & 13 & 0 & 57 & 18 & 24 \\
\hline Maghreb & 33 & 8 & 3 & 44 & 11 & 35 \\
\hline Other Africa & 29 & 10 & 0 & 39 & 15 & 35 \\
\hline Turkey & 42 & 9 & 0 & 51 & 4 & 29 \\
\hline Asia & 29 & 12 & 3 & 44 & 22 & 26 \\
\hline
\end{tabular}

Note: Majority population and immigrants employed in 2014. 